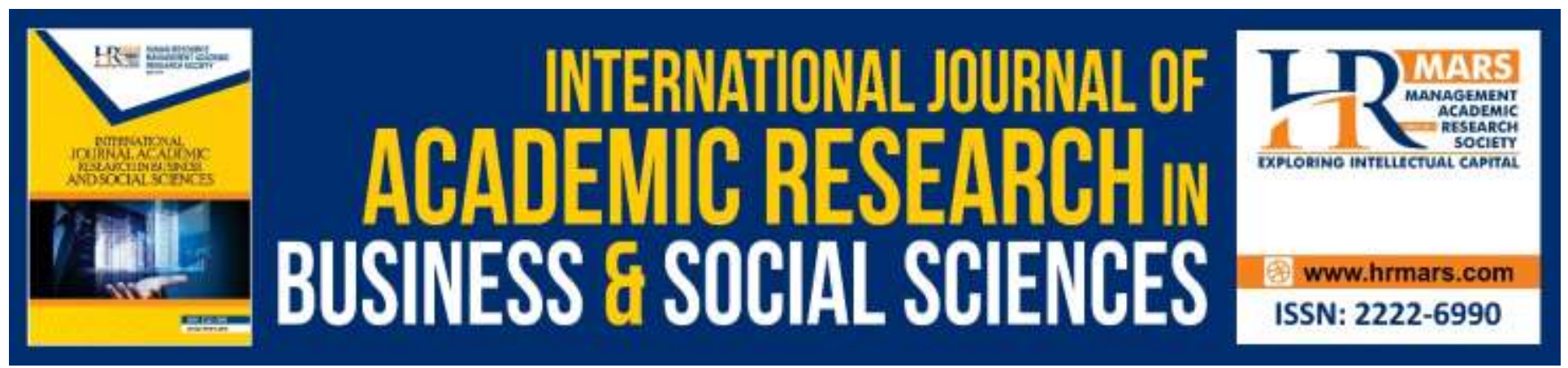

\title{
Chinese language and Culture Interplay in Invigorating Social Development: A Context of Kenya
}

\author{
Mercy Mweni Kathina, Fredrick Okoth Otieno, Peter Gikonyo, Christopher \\ Khayeka-Wandabwa, Methody Florian Owaki
}

To Link this Article: http://dx.doi.org/10.6007/IJARBSS/v10-i4/7130

DOI:10.6007/IJARBSS/v10-i4/7130

Received: 09 February 2020, Revised: 01 March 2020, Accepted: 19 March 2020

Published Online: 17 April 2020

In-Text Citation: (Kathina et al., 2020)

To Cite this Article: Kathina, M. M., Otieno, F. O., Gikonyo, P., Khayeka-Wandabwa, C., \& Owaki, M. F. (2020). Chinese language and Culture Interplay in Invigorating Social Development: A Context of Kenya. International Journal of Academic Research in Business and Social Sciences, 10(4), 295-303.

Copyright: @ 2020 The Author(s)

Published by Human Resource Management Academic Research Society (www.hrmars.com)

This article is published under the Creative Commons Attribution (CC BY 4.0) license. Anyone may reproduce, distribute, translate and create derivative works of this article (for both commercial and non-commercial purposes), subject to full attribution to the original publication and authors. The full terms of this license may be seen

at: http://creativecommons.org/licences/by/4.0/legalcode

Vol. 10, No. 4, 2020, Pg. 295 - 303

Full Terms \& Conditions of access and use can be found at http://hrmars.com/index.php/pages/detail/publication-ethics 


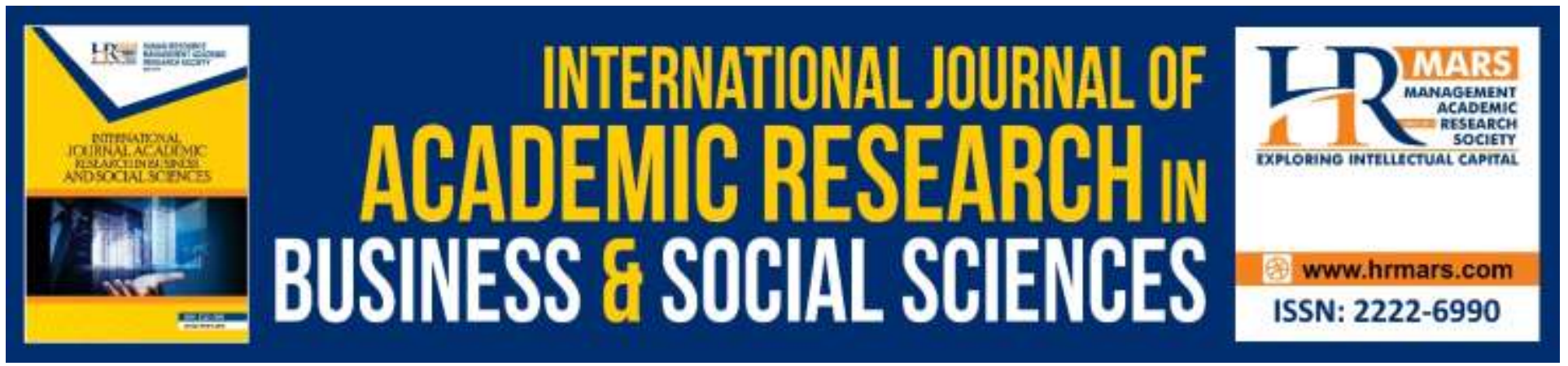

\title{
Chinese language and Culture Interplay in Invigorating Social Development: A Context of Kenya
}

\author{
Mercy Mweni Kathina \\ College of Chinese Language and Literature, Tianjin Normal University, Tianjin City, Xiqing District, \\ Bin Shui West Road No. 393, China. Postal code 300387 \\ Email: kathinamercy@yahoo.com
}

\section{Fredrick Okoth Otieno}

2College of International Education and Exchange, Tianjin Normal University, Balitai campus, 57-1 Wujiayao Avenue, Hexi District, Tianjin, China. Postcode 300074

Email: okothfredrick88@yahoo.com

\section{Peter Gikonyo}

Department of Linguistics and Languages, University of Nairobi Confucius Institute P.O BOX

30197-00100, Nairobi, Kenya

Email: gpetermwai@outlook.com

\section{Christopher Khayeka-Wandabwa}

School of Pharmaceutical Science and Technology (SPST), Health Science Platform, Tianjin

University, Tianjin 300072, China

Email:khayekachris@yahoo.com

\section{Methody Florian Owaki}

College of Chinese Language and Literature, Tianjin Normal University, Tianjin City, Xiqing District, Bin Shui West Road No. 393, China. Postal code 300387

Email: 1824336614@qq.com

\begin{abstract}
Going by the progressive China global opening-up and reform agenda alongside interlinked international influence, it is apparent that knowledge sharing, economic integration and crosscultural communication are increasingly becoming indispensable occasioning the demand for intellectuals, entrepreneurs or employees with a global standpoint. The aim of this perspective is to highlight the introduction and progress of Chinese Language and Culture in Kenya in invigorating
\end{abstract}


social development. Documentary enquiries along with discourse analysis dimensions are applied. Progressively, language teaching was integrated with Chinese culture as a training package to the current prominence from elementary to Bachelor's degree level in about six public and private higher learning institutions. Consequently, the combined program of Chinese language and culture is emerging as one of the fastest growing foreign language programs in Kenya. This has come with strengthened practical bilateral exchanges significantly benefitting the youth courtesy of having competitive exchange programs to language-based universities in mainland China for both short and long term programs the underlying benefits being multi-cultural exposure, deeper mutual understanding and gainful socioeconomic pursuits. Language and culture exchange programs between China and Kenya among beneficiary learners has gone a long way in instilling deeper mutual understanding between the two nations with enhanced intellectual and economic ties across fields. However, despite the close relation between language, culture and environment, the introduction of Chinese culture in teaching of Chinese as a second language is of multi-faceted complexity to new learners that have not had an actual experience of China thus more exchange programs should be fostered.

Keywords: Chinese Language, Chinese Culture, Teaching, China, Kenya.

\section{Introduction}

China's cooperation with Africa has a long and notable history, dating back to the 1950s. In the past decades, China's expanding engagement with Africa in the field of international development assistance has attracted great attention and given rise to mixed reactions and debate at the international level (Yamada \& Niu, 2014). The turn of the millennium has seen China stepping up diplomatic and economic links with Africa, resulting in the Forum on China-Africa Cooperation (FOCAC)(Alden \& Large, 2018) among a series of similar Sino-Africa platforms. Courtesy of this growing ties, there has been a wave of increased economic attention to Africa by state-influenced companies as well as private entrepreneurs who are arguably among the new shapers of development in Africa (Broadman, 2006). Moreover, there are indications that the Chinese are set to increase investment across the continent leading to further socio economic ties (Mohan \& TanMullins, 2009). There is no doubt China-Africa relations have advanced significantly, particularly in recent years (Khayeka-Wandabwa et al.; Tambo et al., 2019; Taylor, 2010). Currently, Chinese language and culture learning is one of the in-demand programmes and many learners are enrolling for the language lessons across Africa. This could be attributed to the ties between Africa and China and also the increasing Chinese population as expatriates across Africa with Kenya as a pivot of focus within East Africa. The increase in population of Chinese expatriates in Kenya could be attributed to the business and investment opportunities that bilateral partnerships between Kenya and China has created in the recent years (Yang, 2018).

Chinese has a number of dialects (Mandarin and Cantonese included) but Mandarin, also known as 'Putonghua', which is based on the Northern dialect, is the most spoken dialect in the world; spoken by not only about 900 million natives, but also as a second language by speakers of other Chinese dialects and non-Chinese groups across the world (Haspelmath \& Tadmor, 2009). Both Governmentfunded public institutions and private ones teaching Chinese language and culture are growing at a commendable rate not only across Africa but also across the world. According to the Chinese language council (Hanban), since the establishment of the first Confucius Institute (CI) on the African 
INTERNATIONAL JOURNAL OF ACADEMIC RESEARCH IN BUSINESS AND SOCIAL SCIENCES Vol. 10, No. 4, April, 2020, E-ISSN: 2222-6990 @ 2020 HRMARS

soil at the University of Nairobi, Kenya in December, 2005, the number of Cls and Confucius Classrooms in Africa has grown to 59 and 41 respectively as at June, 2019, being distributed across 44 African countries. These are the centres mandated with the propagation of Chinese language and culture across the world, with their headquarters in Beijing, China (Akhtaruzzaman, Berg, \& Lien, 2017; Wheeler, 2014).

To date, there exists a strategic National Government support to see greater numbers of Kenyan students equipped with linguistic and cultural competence in Chinese language. Plans are underway to include Chinese in the Kenyan education curriculum. Kenya will now teach Mandarin in classrooms in a bid to improve knowledge and skills set competitiveness and facilitate better bilateral exchanges, intellectual gains and interlinked connections with China if the newly rolled out Competence-Based Curriculum (CBC) is to be contextualized in a broader view. The Kenya Institute of Curriculum Development (KICD) has affirmed the design and scope of the mandarin syllabus have been completed and will be rolled out in 2020 where pupils from grade four (aged 10) and onwards will be able to take the language classes. The introduction is courtesy of Mandarin growing globally and being recognized as one of the official languages of the United Nations, the deepening political and economic connections between Kenya and China, and that given the growth of China in the world economy to a stronger capacity, Kenya stands to benefit if its citizens can understand Mandarin (King, 2014; Li, 2018; Taylor, 2010). During deliberations to introduce the language in schools, the officials in Nairobi received support from Beijing over the past few years. A delegation of Chinese scholars helped with developing the courses while scholarships were allotted to Kenyan graduate students to study in Chinese universities.

Following the development of Sino-African economic and trade cooperation in recent years and the inception of the Forum on China-Africa Cooperation (FOCAC), the relationship between China- Africa has also grown steadily (Taylor, 2010). Kenya, being a gateway to Africa because of its technological advancement, more advanced expertise labour market base and strategic location has a close relationship with China. The population of Kenyans learning Chinese has been on the rise partly attributed to the expanding bilateral and scholarship partnership and exchange programs across all level of advanced and continuous professional education for advanced skilled manpower. China has grown to become Africa's most important economic partner, according to research released by McKinsey and Company in 2017 while increasingly creating a large cultural footprint across the world's fastest-growing continent(Manji, Manji, \& Marks, 2007).

Driven by these dynamics, the perspective seeks to highlight the introduction and progress of Chinese Language and Culture in Kenya in invigorating social development facet.

\section{Language and Culture Integration Benefits in Advancing Mandarin}

Evidence suggests ambitious young Africans are increasingly inclined to take up Mandarin as a way to land a dream job in China or benefit from China's growing influence on the continent (Methody, Kathina, Khayeka-Wandabwa, Gichuru, \& Amimo, 2019; Yang, 2018). However, Mandarin being a distinct language is definitely part of a people's culture. Language has been defined by many scholars over the years. Language can be defined as a body of words and the systems for their use, common to a people who are of the same community or nation, the same geographical area, or the same cultural tradition (Santana, 2016; Zalta, Nodelman, Allen, \& Perry, 2003). This definition outlines the intertwined relationship between language and culture, that is, in order to learn a language one 
needs to learn the culture of the target language (TL) so as to have mastery and deeper understanding of the language. Based on compilation around culture (Spencer-Oatey \& Franklin, 2012), culture consists of patterns, explicit and implicit, of and for behaviour acquired and transmitted by symbols, constituting the distinctive achievements of human groups, including their embodiment in artefacts. The essential core of culture comprises traditions (that is historically derived and selected) ideas and especially their attached values (Gudykunst et al., 1996) with set of attitudes, values, beliefs, and behaviours shared by a group of people, but different for each individual, communicated from one generation to the next.

Going by the contextual definitions, it is amenable to affirm that the relationship between language and culture is deeply rooted. Language as a communication tool is used to maintain and convey culture and cultural ties. Different ideas stem from differing language use within one's culture. This article argues that an understanding of people's culture can be enhanced by learning their language. The argument is supported by various scholarly' views on the same (Emmitt, Pollock, \& Komesaroff, 2003) where it is asserted that even though people would be brought up under similar behavioural backgrounds or cultural situations but by virtue of speaking different languages, their perspective on world view may be very different. It is further argued that language is rooted in culture and culture is reflected and passed on by language from one generation to the next(Allwright, Allwright, \& Bailey, 1991) thus, learning a new language involves learning a new culture. From this, we can further contend and say, provided there is an existing situation that involves an individual learning a new language, it always comes with learning of a new culture most probably interlinked to the language. As such, awareness and understanding of a subjective culture is vital to language learning because language cannot be separated from thought and thought is based on assumptions, values and beliefs (Durocher, 2007).

\section{Chinese language and culture dynamism on the Kenyan Chinese language learner}

Putting the language and culture learning into consideration, Kenyans enrolled to study Chinese language in various Kenyan and Chinese institutions, no matter what their interest for the language is, have the mandate to learn the Chinese culture. However, a question arises, how can the vast Chinese culture be taught in an environment with at least 42 tribes with different cultural beliefs and background such as Kenya? Language is so closely entwined with culture; language teachers entering a different culture must respect the cultural values of the places they are in where it is affirmed to teach a foreign language is also to teach a foreign culture, and it is important to be sensitive to the fact that our students, our colleges, our administrators, our neighbours, do not share all of our cultural paradigms (Englebert \& Dong, 2004). Cultural teaching therefore plays a very critical role in Chinese language teaching and learning, for one to truly acquire, master and retain a language then one must understand the culture of the target language as language cannot exist without the culture. Teaching of Chinese is both a kind of language teaching and a kind of cultural teaching. Consequently, in the process of teaching of Chinese, it is necessary to strengthen and pay attention to the input of cultural teaching, which cannot only promote learners' learning of Chinese knowledge, but also stimulate their interest in learning and enhance their confidence in learning Chinese(Hong, Morris, Chiu, \& Benet-Martinez, 2000).

It is argued, when students utilize a learnt language, they may use the language inappropriately or within the wrong cultural context, thus defeating the purpose of learning a language(Hinkel, 1999; 
INTERNATIONAL JOURNAL OF ACADEMIC RESEARCH IN BUSINESS AND SOCIAL SCIENCES Vol. 10, No. 4, April, 2020, E-ISSN: 2222-6990 @ 2020 HRMARS

Jiang, 2000). Therefore, instructional learning given by teachers ought to be integrated with the cultural background of the language in which it ordinarily thrives hence allowing much of attaching meaning to what is being taught. Chinese culture can broadly be viewed as one of the four ancient and most continuous world civilizations (Alden \& Large, 2018; Yang, 2018) which means that students have to integrate it in their attempt to learn Chinese language. But are there any similarities between Chinese and African cultures? Both have long elaborate cultural histories, China being one of the ancient civilizations while Africa being the cradle of human civilization and between the two exists history of contact and communication (Yang, 2018). Language teachers must choose culturally appropriate teaching styles and explore culturally-based linguistic differences to promote understanding instead of misconceptions or prejudices (Hollie, 2017; Methody et al., 2019; Nabi, 2017). Such underpinnings may be viewed as dismal but are likely to have a bearing on social cultural interaction between the foreign learners and indigenous population or the natives of the language in cues of social cohesion and engagement in the people-to people exchange avenues advanced by different bilateral avenues.

The implications of language being completely entwined with culture with regards to language teaching and language policy are far reaching. Language policy must be used to create awareness and understanding of cultural differences and written to incorporate the cultural values of those being taught. The lack of a unified Chinese teaching curriculum amidst its high propagation rate in Kenya is something that should be examined further (Methody et al., 2019). Various Chinese language teaching institutions are currently designing teaching models in accordance to the learners' learning motivation and preferences; and requirements of other educational institutions, from which learning objectives, contents, learning system and learning resources are formulated and selected posing a big challenge to its propagation (Methody et al., 2019). As such, content delivery, curriculum framework and accompanying learning materials and needs ought to be harmonized to meet progressive targets for language acquisition in the CBC driven environment.

The body in charge of making educational policies in Kenya must be sensitive to the local or indigenous languages when coming up with policies governing the teaching and learning of Chinese language and culture so as not to make them seem inferior before the target language. When making policies regarding language teaching, one must consider the cultural ideologies of the students, the teachers as well as the culture in which the target language is being taught. Language teaching policies formed with the cultural characteristics of both teacher and student in mind will not be prone to make assumptions about the appropriateness of students' behaviour based on the policy maker's own cultural values but will increase cultural awareness(Englebert \& Dong, 2004). The American Council on The Teaching of Foreign Languages has expounded on the importance of combining the teaching of culture into the language curriculum to enhance understanding and acceptance of differences between people, cultures and ideologies(National Standards in Foreign Language Education Project, 1996).

Language, culture and context in the people-to-people exchanges, win-win bidirectional and mutual cooperation quests

Overall, focusing on education, language, culture, people to people exchanges and accompanying Sino-African and FOCAC relations alongside bilateral underpinnings (Hanauer \& Morris, 2014; Taylor, 
INTERNATIONAL JOURNAL OF ACADEMIC RESEARCH IN BUSINESS AND SOCIAL SCIENCES

Vol. 10, No. 4, April, 2020, E-ISSN: 2222-6990 @ 2020 HRMARS

2010) develops two dimensions which are evident and continue to be advanced with a futuristic potential:

\section{There is Progressive Education and Language Exchange Policy Promotions}

Through FOCAC and other Sino-Africa platforms, Chinese Government Scholarship (CGS) with a core target to African students has increased progressively. In 2006 for instance, it was scaled from 2000 to about 4000 annually and this increase was so in subsequent summits (King, 2014; Li, 2018). In 2012, during the fifth Ministerial Conference of the FOCAC it was clear the scholarships would keep rising in the next three years as promised by the Chinese government and by 2015 African CGS holders reached more than 8,400 amidst careful implementation policies and strategies planned by different players: universities, municipalities, various departments, and even individuals within the Chinese governance and leadership(Li, 2018). In a spirit of win-win cooperation, the upsurge of Africans and other foreigners among the Chinese locals has promoted the need for Chinese to learn foreign languages like English, Swahili and French, an area of strength that African nations can leverage based on their clustered regional strength for instance English and Swahili experts from East Africa for better prosperity between the two regions and country specific partnership in socio economic exchanges of human capital through education (Khayeka-Wandabwa et al.). The African and by extension Kenyan leading education institutions interested in such strategic direction, would have a benefit of learning from underlying core needs and achievements attained by Chinese institutions in domiciling foreign language and culture programs in their higher learning institutions(Li, 2018) for easy adaptation of the same to fit and attract Chinese learners to Africa. Such provisions potential would be adapted from FOCAC guiding pillars.

\section{Power in Numbers and 'Win-win' Engagement}

In bilateral exchanges with a focus on trade, security and diplomacy, this is well articulated through education, language and culture exchanges as it is already being debated and validated by evidence available (Hanauer \& Morris, 2014; King, 2014; Li, 2018). As advanced by trends in the field of education, China is clearly an attractive destination for international studies for Africans, apart from its scholarship provision. For instance, whereas estimated scholarship numbers by the year 2011 were just over 6,000; the self-financed students were more than double (over 14,000). The same point could be made about China's formal promotion of Mandarin and Chinese culture and history via its Confucius Institutes and Confucius Classrooms. In all these it is hoped and anticipated that, the experience these African students get in China would translate into a willingness to work with China and view China's internal or external policies favourably in the future. On the other hand it is argued African students that head to China have a range of reasons; some simply go to pursue an education that is affordable, even without a scholarship, while others go for the chance to develop business connections or learn the language of a country presumed to be a rising power hence a leverage to better economic ties and prospects (Hanauer \& Morris, 2014; King, 2014; Li, 2018; Methody et al., 2019; Taylor, 2010).

\section{Conclusion}

Language and culture exchange programmes between China and Kenya among beneficiary learners has gone a long way in instilling deeper understanding of the language hence stimulating enhanced 
INTERNATIONAL JOURNAL OF ACADEMIC RESEARCH IN BUSINESS AND SOCIAL SCIENCES Vol. 10, No. 4, April, 2020, E-ISSN: 2222-6990 @ 2020 HRMARS

localized intellectual and economic ties across various fields. It is evident, language and culture are intertwined to such an extent where for one to successfully learn a language, culture associated with that language would be integral as well. Despite the close relations between language, culture and environment, the introduction of Chinese culture in teaching of Chinese as a second language is of certain complexity to new learners that have not had an actual experience of China and as such more exchange programmes should be fostered.

The body that is mandated with developing Chinese language and culture program should come up with a unified curriculum so that both learners and teachers can extensively learn and teach Chinese considering all levels of the anticipated CBC curriculum in Kenya. In doing so, (1) Progressive education and language exchange policy promotions programmes and (2) Power in numbers and 'Win-win' engagement through FOCAC and various Sino-Africa initiatives(Kathina et al., 2018; Methody et al., 2019) for not only education exchanges but also economic and entrepreneurship ties, skills transfer alongside exchange of labour force based on strength of each nation across fields will in the coming years contribute immensely to social development ties between China and Africa at large.

\section{References}

Akhtaruzzaman, M., Berg, N., \& Lien, D. (2017). Confucius Institutes and FDI flows from China to Africa. China Economic Review, 44, 241-252.

Alden, C., \& Large, D. (2018). New Directions in Africa-China Studies: Routledge.

Allwright, R., Allwright, D., \& Bailey, K. M. (1991). Focus on the language classroom: An introduction to classroom research for language teachers: Cambridge University Press.

Broadman, H. G. (2006). Africa's silk road: China and India's new economic frontier: The World Bank.

Durocher, Jr. D. O. (2007). Teaching sensitivity to cultural difference in the first-year foreign language classroom. Foreign Language Annals, 40(1), 143-160.

Emmitt, M., Pollock, J., \& Komesaroff, L. (2003). Language and learning: An introduction for teaching: Oxford University Press.

Englebert, M., \& Dong, S.-b. (2004). Character or Culture? Implications for the Culturally Diverse Classroom. Asian EFL Journal March.

Gudykunst, W. B., Matsumoto, Y., Ting-Toomey, S., Nishida, T., Kim, K., \& Heyman, S. (1996). The influence of cultural individualism-collectivism, self construals, and individual values on communication styles across cultures. Human communication research, 22(4), 510-543.

Hanauer, L., \& Morris, L. J. (2014). China in Africa: Implications of a deepening relationship. Santa Monica, CA: RAND Corporation.

Haspelmath, M., \& Tadmor, U. (2009). Loanwords in the world's languages: a comparative handbook: Walter de Gruyter.

Hinkel, E. (1999). Culture in second language teaching and learning: Cambridge University Press.

Hollie, S. (2017). Culturally and linguistically responsive teaching and learning: Classroom practices for student success: Teacher Created Materials.

Hong, Y.-y., Morris, M. W., Chiu, C.-y., \& Benet-Martinez, V. (2000). Multicultural minds: A dynamic constructivist approach to culture and cognition. American psychologist, 55(7), 709.

Jiang, W. (2000). The relationship between culture and language. ELT journal, 54(4), 328-334. 
INTERNATIONAL JOURNAL OF ACADEMIC RESEARCH IN BUSINESS AND SOCIAL SCIENCES

Vol. 10, No. 4, April, 2020, E-ISSN: 2222-6990 @ 2020 HRMARS

Kathina, M. M., Khayeka-Wandabwa, C., Muchiri, G. W., Wamalwa, S., Gichuru, F. M., Marinda, P., \& Tambo, E. (2018). Leveraging Bi-directional Language Exchange Programs in Forum on ChinaAfrica Cooperation for Enhanced Economic Cooperation, Research and Development: Perspective: Beijing, China: Peking University (PKU) Africa Think Tank.

Khayeka-Wandabwa, C., Gichuru, F. M., Kathina, M. M., Marinda, P., Muchiri, G. W., Tambo, E., \& Wamalwa, S. Leveraging Bi-directional Language Exchange Programs in Forum on ChinaAfrica Cooperation for Enhanced Economic Cooperation, Research and Development: Perspective.

King, K. (2014). China's Higher Education Engagement with Africa: A Different Partnership and Cooperation Model? Education, learning, training: critical issues for development, 151-173.

Li, A. (2018). African students in China: Research, reality, and reflection. African Studies Quarterly, $17(4), 5-44$.

Manji, F. M., Manji, F., \& Marks, S. (2007). African perspectives on China in Africa: Fahamu/Pambazuka.

Methody, F. O., Kathina, M. M., Khayeka-Wandabwa, C., Gichuru, F. M., \& Amimo, E. (2019). Chinese Language Teaching and Learning in Kenya in the Prospects of China's Reform and Openingup. Educational Process: International Journal, 8(3), 170.

Mohan, G., \& Tan-Mullins, M. (2009). Chinese migrants in Africa as new agents of development? An analytical framework. The European Journal of Development Research, 21(4), 588-605.

Nabi, A. (2017). Language and Culture. Journal of Humanities and Social Sciences, 22, 91-94.

National Standards in Foreign Language Education Project, Y., NY. (1996). Standards for foreign language learning: Preparing for the 21st century: ERIC Clearinghouse.

Santana, C. (2016). What Is Language? Ergo, an Open Access Journal of Philosophy, 3.

Spencer-Oatey, H., \& Franklin, P. (2012). What is culture. A compilation of quotations. GlobalPAD Core Concepts, 1-22.

Tambo, E., Khayeka-Wandabwa, C., Muchiri, G. W., Liu, Y.-N., Tang, S., \& Zhou, X.-N. (2019). China's Belt and Road Initiative: Incorporating public health measures toward global economic growth and shared prosperity. Global Health Journal.

Taylor, I. (2010). The Forum on China-Africa Cooperation (FOCAC): Routledge.

Wheeler, A. (2014). Cultural diplomacy, language planning, and the case of the University of Nairobi Confucius Institute. Journal of Asian and African studies, 49(1), 49-63.

Yamada, S., \& Niu, C. (2014). China's educational cooperation with Africa: toward new strategic partnerships. Asian Education and Development Studies.

Yang, Q. (2018). A New Era in China-Africa Friendly Cooperation: New Achievements, New Opportunities, New Vision: Zhongguo she hui ke xue chu ban she.

Zalta, E. N., Nodelman, U., Allen, C., \& Perry, J. (2003). Stanford encyclopedia of philosophy: Stanford University. The Metaphysics Research Lab. 